\title{
The Authority and the Membership of the Commission in the Future
}

\author{
Mónica Pinto
}

\section{Introduction}

The legal and political world order established after the Second World War envisaged a multilateral arena where States could have more interaction than in the past. International law aspired to deal with a larger field of objects in the relations among States. It also saw the end of the colonial world and, thus, an increase in the number of States. Soon after this new order's implementation, the question of the new subjects and their international legal capacity became an issue.

The enlargement of the field of the objects of international law and the increasing number of States led to the conclusion that there was a need for precise and universal rules, acceptable to all States, existing or yet to be created.

The Charter of the United Nations acknowledged that feature of the emerging international community and in Article 13, paragraph 1 (a), provided that the only plenary body of the United Nations - the General Assembly - should "initiate studies and make recommendations for the purpose of promoting international co-operation in the political field and encouraging the progressive development of international law and its codification". Consequently, in its resolution 174(II), the General Assembly established the International Law Commission to give effect to this Charter provision, and it also offered a description of what constitutes progressive development and codification, respectively. ${ }^{1}$ Other colleagues have already addressed this issue in detail and with merit. ${ }^{2}$ What I would like to stress here is that, shortly after commencing its work, the International Law Commission realized that making the distinction between progressive development and codification was not easy, and as early as in 1956, the Commission gave up any pretence to be strict in that differentiation. ${ }^{3}$

In fact, as it was emphasized by Secretary-General Dag Hammarskjöld, "[t]he reluctance of Governments to submit their controversies to judicial

1 UNGA Res 174 (II) (21 November 1947).

2 See the contributions in Section 5 of this volume.

3 José Alvarez, International Organizations as Law-Makers (OUP 2006) 308. 
settlement stems in part from the fragmentary and uncertain character of much of international law as it now exists". ${ }^{4}$ It was then necessary to make rules of international law more certain and evident. ${ }^{5}$

The International Law Commission was the engineer in the establishment of the "essential building blocks in the development of the post-war international legal system", 6 producing a series of draft conventions in the 1950s and 1960 s that were almost universally endorsed. But in the 1970 and 1980 os its impact seemed to be decreasing, mainly because of the relatively low number of ratifications of the conventions in the field of succession of States (the convention dealing with succession in respect of treaties currently has only 22 States parties, ${ }^{7}$ while that in respect of State property, archives and debt ${ }^{8}$ has so far obtained only 7 of the 15 ratifications it needs to enter into force).

Legal scholars referred to the crisis of the International Law Commission and, in a study of the United Nations Institute for Training and Research (UNITAR), Thomas Franck, Mohamed ElBaradei and Robert Trachtenberg called for a new direction. The critique emphasized that the International Law Commission remained in its comfort zone and avoided addressing the changing priorities of the international community. ${ }^{9}$

The 199os brought about some changes. On the one hand, in a couple of years, the International Law Commission succeeded in forwarding to the General Assembly a draft convention for the establishment of an international criminal court. ${ }^{10}$ In the same year, on the other hand, the International Law Commission produced another set of draft articles which were later adopted as a convention, ${ }^{11}$ the Convention on the Law of Non-Navigational Uses of

4 'Annual Report of the Secretary-General on the Work of the Organization, 1 July $1954-15$ June 1955' (1955) UN Doc A/2911.

$5 \quad$ Luke T Lee, 'The International Law Commission Re-Examined' (1965) 59 AJIL 545, 546.

6 Thomas Franck and Mohamed ElBaradei, 'The Codification and Progressive Development of International Law: A UNITAR Study of the Role and Use of the International Law Commission' (1982) 76 AJIL 63o, 631.

7 Vienna Convention on Succession of States in respect of Treaties, adopted 23 August 1978, entered into force 6 November 1996, 1946 UNTS 3.

8 Vienna Convention on Succession in respect of State Property, Archives and Debts (adopted in Vienna on 8 April 1983, not yet in force) (1983) 22 ILM 306.

9 Mohammed ElBaradei, Thomas M. Frank, Robert Trachtenberg, The International Law Commission: The Need for a New Direction (UNITAR 1981).

10 ILC, 'Draft Statute for an International Criminal Court, with commentaries' [1994] II(2) ILC Ybk 26; 'Draft code of crimes against the peace and security of mankind' [1996] II(2) ILC Ybk 15 .

11 ILC, 'Draft articles on the law of the non-navigational uses of international watercourses' [1994] II(2) ILC Ybk 89. 
International Watercourses, but this convention would take until 2014 to enter into force (ratified by only 36 States as of today). ${ }^{12}$

The Rome Statute of the International Criminal Court was adopted on 17 July 1998 and entered into force on 1 July 2002, being binding today for 123 States. ${ }^{13}$ It is the constitutional text of one of the major developments of postwar international law. It established a full-fledged court that has worked on 28 cases $^{14}$ with a view to ending impunity and delivering justice.

Not all the products of the International Law Commission are intended to become treaties or are endorsed by States in the form of treaties. In the past, that was the case for the summary conclusions on the most-favoured nation clause, ${ }^{15}$ the status of diplomatic courier and the bag of international organizations of a universal character, ${ }^{16}$ State responsibility for internationally wrongful acts, ${ }^{17}$ prevention of transboundary damage from hazardous activities, ${ }^{18}$ diplomatic protection, ${ }^{19}$ expulsion of aliens, ${ }^{20}$ the protection of persons in the event of disasters, ${ }^{21}$ or the draft conclusions on subsequent agreements and subsequent practice in relation to interpretation of treaties. ${ }^{22}$ The International Law Commission also adopted draft guidelines on reservations to treaties and produced a guide to practice on reservations to treaties with a view to assisting practitioners. ${ }^{23}$ These products of the Commission, which deserve the same attention as others that became treaties, have played an important role in international law.

12 Convention on the Law of Non-Navigational Uses of International Watercourses, adopted 21 May 1997, entered into force on 17 August 2014, UNTS registration no 52106 (number of ratifications as of 26 December 2018).

13 Adopted 17 July 1998, entered into force 1 July 2002, 2187 UNTS 3 (number of ratifications as of 26 December 2018).

14 An overview is available at $<$ www.icc-cpi.int/cases $>$ (as of 26 December 2018).

15 ILC, 'Summary Conclusions on the Most-Favoured-Nation Clause' (2015) UN Doc A/70/10, 19 at para 42.

16 ILC, 'Draft optional protocol two on the status of the courier and the bag of international organizations of a universal character' [1989] II (2) ILC Ybk 48.

17 ILC, 'Draft articles on responsibility of States for internationally wrongful acts' [2001] II(2) ILC Ybk 26.

18 ILC, 'Draft articles on prevention of transboundary harm from hazardous activities' [2001] II(2) ILC Ybk 146.

19 ILC, 'Draft articles on diplomatic protection' [2006] II(2) ILC Ybk 24.

$20 \quad$ ILC, 'Draft articles on the expulsion of aliens' (2014) UN Doc A/69/10, 11.

21 ILC, 'Draft articles on the protection of persons in the event of disasters' (2016) UN Doc A/ $71 / 10,13$.

22 ILC, 'Report of the International Law Commission on the work of its seventieth session' (2018) UN Doc A/73/10, 12 at para 49.

23 ILC, 'Guide to practice on reservation to treaties' [2011] II(3) ILC Ybk 23. 
At present, the International Law Commission has 34 members, all of whom serve in their personal capacity. According to article 8 of the statute of the International law Commission, they should - globally - represent the main forms of civilization and the principal legal systems of the world.

The purpose of this paper is to critically assess and offer insights regarding the membership and authority of the International Law Commission in the future.

\section{The Composition of the International Law Commission}

The main professions represented in the International Law Commission are diplomacy and legal services; to a lesser extent also academia. It has been stressed that when legal advisors and judges or members of the ministries of justice sit on the Commission, it may be difficult for them to avoid approaching their work from a semi-official perspective. ${ }^{24}$ Be that as it may, it seems that litigants, i.e. those involved mainly in international judicial activities, are not given a reasonable place on the Commission. Some of the International Law Commission's members, at present and in the recent past, have worked as legal counsels in more than one case before the International Court of Justice, for instance, but right now there are not more than three or four members of the Commission that have represented States before the Court. ${ }^{25}$ Since litigation is an activity frequently conducted jointly with the performance of academic roles, the risk that litigants may tend to tailor rules in a way that is favorable to their cases is ultimately curtailed by the prestige each of them earns throughout their careers.

The International Law Commission's members have been and are mostly men. At present, the Commission has four women among its members - Concepción Escobar Hernández, Patrícia Galvão Teles, Marja Lehto, and Nilüfer Oral - which amounts to 11.75 per cent. Women have only been elected to the Commission since the turn of the century. From 2002 to 2010, only two women, that is 5.88 per cent, worked in the International Law Commission with their male colleagues, Paula Escarameia of Portugal and Hanqin Xue of China, who became the first female Chair of the Commission. They were joined by Marie Jacobsson, so from 2007 until 2011 there were three female members of the Commission. Yet again, between 2011 and 2016 there were only two female members, Marie Jacobsson and Concepción Escobar Hernández.

\footnotetext{
24 Lee ( $\left.\mathrm{n}_{5}\right) 55 \mathrm{O}$.

25 See the Concluding Remarks to this Section by Dire Tladi.
} 
In light of this imbalance of gender representation, there are convincing bases to improve this situation. Gender studies provide at least two sets of arguments to that end, those relying on the special contribution women make to international law, and those rooted in considerations of equity and fairness. Thus, it is possible to submit that they, or we, have to be more adequately represented because of our special position as women. But there are surely other arguments in favour of gender parity based on the principle of fairness, which implies that the increase in the number of women scholars ${ }^{26}$ in international law should be reciprocated in the composition of the Commission. ${ }^{27}$ I support the latter argument. States should be encouraged to nominate and elect women to be members of the Commission. The International Law Commission itself may adopt some policy on this matter just encouraging States to reach parity when proposing candidates.

Another feature that is to be considered is the lack of new generations in the International Law Commission's composition. The average age of the members is around 55 years, with individual ages ranging from 35 to 82 years. This means that almost all members obtained their law degrees by the late $1980 \mathrm{os}$ and consequently might not have the necessary knowledge with regard to new technologies or of some of the new developments in the big picture of international law during their studies. Their "co-habitation" with new generations, those in their mid-forties, could provide the International Law Commission with even more intellectual capacity to progressively develop and codify international law.

The allocation of the Commission's membership among the regional groups (the African Group and Western European and Others Group with 8 members each, the Latin American and Caribbean Group and Asia-Pacific Group with 7 members each and Eastern Europe with 4 members $)^{28}$ roughly corresponds to the distribution of population around the world, but it is not translated to the level of the appointment of Special Rapporteurs of the Commission. In fact, of the 61 Special Rapporteurs listed on the International Law Commission's

26 Elizabeth Olson, 'Women Make Up Majority of U.S. Law Students for First Time', The New York Times, 16 December 2016; Staci Zaretsky, 'There Are Now More Women In Law School Than Ever Before', Above The Law, 7 March 2018. Another example is provided by the University of Buenos Aires Law School, where the 6o per cent of students are women: see Universidad de Buenos Aires, 'Resultados de Finales' (2011), available at <http://www.uba.ar/institucional/censos/Estudiantes2o11/estudiantes2o11.pdf >.

27 Kate Malleson, 'Justifying Gender Equality on the Bench: Why Difference Won't Do' (2003) 11 FemLS 1.

UNGA Res 36/39 (18 November 1981), para 3 . 
webpage, ${ }^{29}{ }^{31}$ belong to the Western European and Others Group, 9 to Eastern Europe, 9 to the Latin American and Caribbean Group, 7 to the African Group and 5 to the Asia Pacific Group.

Fifty per cent of the Special Rapporteurs of the Western European and Others Group come from the common law system. However, at present, only 5 members of the International Law Commission belong to countries with a common law tradition. Africa's representation among the International Law Commission's Special Rapporteurs is mainly francophone and from Maghreb countries. The Commission's imbalance is illustrated by its work on the law of treaties, custom and State responsibility where Special Rapporteurs have all been white and male, generally from common law countries, nearly always from North America and Europe. It may therefore be questioned whether the work of the Commission reflects "the main forms of civilization and of the principal legal systems of the world", as stipulated in article 8 of its statute.

As the international community has become increasingly multicultural and diverse, efforts should be made to incorporate those trends into the work of the Commission by nominating candidates from other systems of law. Those systems are generally in a minority position and survive in contexts in which one of the more widely spread legal systems prevail. Due to their difficult standing, those legal systems are used to legal syncretism. Their views should be valuable in enriching the Commission's work.

The authority of the International Law Commission in paving the way for the written, more certain, rules of post-war international law is undisputed. However, when the Commission was close to reaching its forties, it experienced a crisis, mainly because its products seemed of less interest to the community of States. Comments by Sixth Committee delegates were not favorable at all. Delegations pointed out that the Commission preferred its needlepoint in safe domains as diplomatic courier and bag, instead of focusing on the challenging issues of the evolving international law. It was also noted that the role of the Commission as a diverse mediator between the interests of established and recently independent States was, in part, challenged by its formalistic approach to international law. ${ }^{30}$

29 ILC, 'Membership: Special Rapporteurs of the International Law Commission (19492016)', available at <http://legal.un.org/ilc/guide/annex3.shtml >.

30 Mathias Forteau, 'Comparative International Law Within, Not Against, International Law: Lessons from the International Law Commission’ (2015) 109 AJIL 498, 502-503. 
That critique was the perception of a unique moment in the international community, that of the first years of the "new States". As time passed, these States became actors in different contexts and demonstrated their respective differences. Their reactions to the International Law Commission's work have also been heterogeneous.

The trend towards "hard law" in the classic work of the International Law Commission stands in contrast to the success of those products of the Commission which have not yet or were never intended to become a binding treaty. This so-called "soft" approach ${ }^{31}$ proved to be effective as they are invoked by the parties in different litigation and by the tribunals. In fact, for instance, the International Court of Justice relied on the articles on State responsibility for internationally wrongful acts - the drafting of which was begun by Francisco García Amador, continued by Roberto Ago, Gaetano Arangio Ruiz, William Riphagen and was finalized by James Crawford - more than once in its judgments. ${ }^{32}$ Moreover, as early as 1997, the International Court of Justice considered that a number of provisions in the then draft articles on State responsibility reflect lex lata. ${ }^{33}$

Other articles have also assisted adjudicators and litigants. Before the International Court of Justice, for instance, Nicaragua relied on the articles on prevention of transboundary harm from hazardous activities; ${ }^{34}$ Uruguay did the same in the case with Argentina relating to the Pulp Mills. ${ }^{35}$

31 Alvarez (n 3) 310, 312. Daugirdas pointed out that the International Law Commission "reinvented itself", see Kristina Daugirdas 'The International Law Commission Reinvents Itself' (2014) 108 AJIL Unbound 7.

Inter alia, Obligations concerning Negotiations relating to Cessation of the Nuclear Arms Race and to Nuclear Disarmament (Marshall Islands $v$ India) (Jurisdiction and Admissibility) [2016] ICJ Rep 255, para 42; Ahmadou Sadio Diallo (Republic of Guinea $v$ Democratic Republic of the Congo) (Compensation) [2012] ICJ Rep 324, para 49; Request for Interpretation of the Judgment of 31 March 2004 in the Case concerning Avena and Other Mexican Nationals (Mexico v United States of America) [2009] ICJ Rep 3, para 64; Application of the Convention on the Prevention and Punishment of the Crime of Genocide (Bosnia and Herzegovina $v$ Serbia and Montenegro) (Merits) [2007] ICJ Rep 43, para 17; Armed Activities on the Territory of the Congo (Democratic Republic of the Congo $v$ Uganda) (Merits) [2005] ICJ Rep 168, paras 16o, 293; Legal Consequences of the Construction of a Wall in the Occupied Palestinian Territory (Advisory Opinion) [2004] ICJ Rep 136, para 140.

33 Gabcikovo-Nagymaros Project (Hungary/Slovakia) (Merits) [1997] ICJ Rep 7, para 47.

34 Certain Activities Carried Out by Nicaragua in the Border Area (Costa Rica v Nicaragua) and Construction of a Road in Costa Rica along the San Juan River (Nicaragua v Costa Rica) (Merits) [2015] ICJ Rep 665, para 190.

35 Pulp Mills on the River Uruguay (Argentina v Uruguay) (Merits) [2010] ICJ Rep 14, paras $152,203,215$. 
Arbitral tribunals have relied on many pieces produced by the International Law Commission. Perhaps because, as José Alvarez pointed out, quoting David Caron,

courts and arbitral panels, such as those charged with resolving investorstate disputes arising under bilateral investment treaties (BIT s), will turn to whatever is available and the ILC's Articles, soft or not, provide a handy recourse for those who need to fill a legal vacuum or who simply desire ostensibly "neutral" authoritative distillation of what would otherwise be an arduous search through innumerable digests of state practice to find applicable rules of custom. ${ }^{36}$

Many arbitral awards illustrate Caron's views. ${ }^{37}$

As a hybrid product, between articles and conventions, there is the Commission's guide to practice on reservations to treaties, ${ }^{38}$ which is meant to provide assistance to practitioners based on and with the authority of an existing treaty, namely the Vienna Convention on the Law of Treaties. ${ }^{39}$

\section{Conclusions}

All these comments lead to some conclusions. One of them is that, at this point in the evolution of the international community and of international law, there seems to be no urgent need for new treaties. The International Law Commission adapted to this trend and produced other forms of outcomes. However, this way of working on the codification and progressive development of international law places States in the margins of the game. States are not invited to have a say with regard to the processes and the final product of the work of the Commission, and neither are other actors, which are generally outside the International Law Commission's scope of action and consultation. It may

$3^{6} \quad$ See Alvarez $\left(\mathrm{n}_{3}\right) 312$.

37 ICSID Case No ARB/15/21, 24 dealing with the draft articles on most-favoured-nation clauses; ICSID Case No ARB $/ 14 / 8,22$ quoting the articles on diplomatic protection; ICSID Case No ARB/13/33, para 87 referring to the draft articles on most-favoured-nation clauses; ICSID Case No ARB/o6/2, 178 referring to the articles on State responsibility for internationally wrongful acts; ICSID Case No ARB/14/3, para 191 dealing with the articles on State responsibility; ICSID Case No ARB/12/35, 291, dealing with the articles on diplomatic protection.

$38 \quad$ ILC, 'Guide to practice on reservations to treaties' [2011] II(3) ILC Ybk 23.

39 Adopted 23 May 1969, entered into force 27 January 1980, 1155 UNTS 331. 
be that the interaction with the Sixth Committee replaces the lack of States' participation, but this cannot be said with certainty.

If the International Law Commission is going to further develop products other than draft articles, it may wish to consider consulting a broader field of stakeholders. In areas like environmental law, non-State actors are crucial as others whose opinions at least should be heard by the International Law Commission. This is illustrated by the work of the Commission on the topic "Protection of the environment" in which the Commission has regularly consulted with experts in the field. ${ }^{40}$ If the International Law Commission's legitimacy is epistemic or technical, because of its methods or because of the expertise of its members, not many reasons would speak against more open and participatory procedures. Academia, litigants, non-governmental organizations and others may offer some important views with regard to the International Law Commission's work.

Some approaches chosen for the new ways of "packaging" the outcome of the Commission's work ${ }^{41}$ such as those on the identification of customary international law subsequent agreements and subsequent practice in relation to the interpretation of treaties, are especially useful for litigation in all fields.

At the end of the day, as Tom Franck and Mohamed ElBaradei put it, the International Law Commission is " $[\mathrm{t}]$ he only drafting body with versatile jurisdiction over any subject in the field of international law". ${ }^{42}$

The International Law Commission is a high-quality brand that could adapt to contextual changes in the past. It will find the ways to raise its profile and to further enhance the level of its brand in the future.

40 ILC, 'Fifth report by the Special Rapporteur on Protection of the Atmosphere' (2018) UN Doc A/CN.4/711, para 2.

41 See Sean Murphy, 'Codification, Progressive Development or Scholarly Analysis? The Art of Packaging the ILC's Work Product' in Maurizio Ragazzi (ed), The Responsibility of International Organizations: Essays in Memory of Sir Ian Brownlie (Martinus Nijhoff 2013). Emphasis in original. See Franck and ElBaradei (n 6) 631 (emphasis in the original). 